\title{
THE SPECIFIC STRUCTURE OF COMPOUNDS EFFECTING FAT MOBILIZATION IN MAN *
}

\author{
By MORTON D. BOGDONOFF, JOSEPH W. LINHART, ROBERT J. KLEIN AND \\ E. HARVEY ESTES, JR. \\ (From the Department of Medicine, Duke University Medical Center and Durham VA \\ Hospital, Durham, N. C.)
}

(Submitted for publication May 1, 1961 ; accepted July 27, 1961)

Both epinephrine and norepinephrine enhance the process of fat mobilization. This property of promoting lipolysis has been observed both in vitro by demonstrating the release of free fatty acids (FFA) and glycerol from adipose tissue within the medium, and in vivo by the increase in the levels of plasma FFA in the fasted, resting individual (1-3). It was the intent of this study to determine whether the property of lipolysis was a singular characteristic of epinephrine and norepinephrine or whether other catechols and other vasoactive substances also could promote fat mobilization. It is known that a certain structureactivity relationship exists for the various sympathomimetic compounds as well as for other classes of drugs. It was of interest to determine whether lipolysis was also dependent upon a specific chemical structure.

\section{METHODS}

Volunteer male subjects or patients without known metabolic disorders were studied after an overnight fast. After being brought to the laboratory the individual was placed in the supine position. Cournand needles were inserted into antecubital veins of both arms, and all effort was made to reduce conversation or external stimuli. A series of two to three preinfusion ("control") samples was then drawn 10 to 15 minutes apart. A 15minute period of infusion of the test substance was then begun, with a Bowman constant infusion pump. After the infusion, samples were drawn at $0,10,20,30,45$, and 60 minutes. Blood pressure was measured by the cuff technique. The total period of observation did not exceed 120 minutes from the time the subject "entered the laboratory until the last :samples was drawn. All blood samples were drawn into, heparinized syringes and immediately chilled. Plasma FFA was measured by a modification of the Dole technique (4).

* Supported by North .Carolina Heart Association, Life Insurance Medical Research Fund, Irwin Strassburger Memorial Fund and Duke University Center for the Study of Aging (H-3582 and M-2109).
RESULTS

The initial studies were directed at developing a "standardized" or "control" method of assay of compound activity. The first set of observations was made on 20 fasting subjects who were kept in the supine, resting position for the entire study, receiving an intravenous infusion of 0.9 per cent saline. The mean $( \pm 1 \mathrm{SE})$ peak rise in plasma FFA (when compared with the immediate preinfusion value) for this group was $150 \pm 42$ $\mu \mathrm{Eq}$ per L. This method of assessing the change in plasma FFA level was used for all studies. The second set of observations was designed to determine the response to both norepinephrine and epinephrine when administered in amounts that do not produce symptoms in the subject. The mean ( $\pm 1 \mathrm{SE}$ ) peak rise for norepinephrine at a rate of $10 \mu \mathrm{g}$ per minute (total dose, $0.150 \mathrm{mg}$ ) in 12 subjects was $640 \pm 110 \mu \mathrm{Eq}$ per $\mathrm{L}$; and for epinephrine at a rate of $2 \mu \mathrm{g}$ per minute (total dose, $0.030 \mathrm{mg}$ ) in 7 subjects, it was $986 \pm$ $205 \mu \mathrm{Eq}$ per L. These rates of infusion exceeded the minimal amount of both norepinephrine and epinephrine that would produce a rise in plasma FFA level exceeding the "control" response of $150 \pm 42 \mu \mathrm{Eq}$ per L (3). For norepinephrine the minimally effective dose was $2 \mu \mathrm{g}$ per minute (total dose, $0.0075 \mathrm{mg}$ ). It is in reference to these initial observations, both as to the magnitude of a peak response and to the minimally effective amount, that the remainder of the compounds were evaluated.

Table I lists the peak response in FFA levels for all compounds studied. Isoproterenol (Isuprel) alone consistently effected a peak response of significant magnitude. It should be noted that many of the compounds failed to result in a significant rise in FFA level when infused in amounts greatly exceeding the effective lipolytic 
TABLE I

Peak FFA and blood pressure response to intravenous infusion of catechol compounds and vasoactive polypeptides

\begin{tabular}{|c|c|c|c|c|}
\hline Compound & Subjects & $\begin{array}{l}\text { Total } \\
\text { dose }\end{array}$ & Peak $\triangle F F A$ & Peak B.P. $\Delta$ \\
\hline 1. Saline & 20 subj. & $\begin{array}{l}m g \\
0.780\end{array}$ & $\begin{array}{c}\mu E q / L \\
\text { Mean } \pm \mathrm{SE}: \\
+150 \pm 42\end{array}$ & $\begin{array}{c}m m \mathrm{Hg} \\
+10 /+5\end{array}$ \\
\hline 2. Norepinephrine & 12 subj. & 0.150 & $\begin{array}{l}\text { Mean } \pm S E: \\
\quad+640 \pm 110\end{array}$ & $+30 /+20$ \\
\hline 3. Epinephrine & 7 subj. & 0.030 & $\begin{array}{l}\text { Mean } \pm \text { SE: } \\
\quad+986 \pm 205\end{array}$ & $+30 /+5$ \\
\hline 4. Isoproterenol & $\begin{array}{l}\text { L.C. } \\
\text { R.J. }\end{array}$ & $\begin{array}{l}0.032 \\
0.032\end{array}$ & $\begin{array}{l}+722 \\
+1,726\end{array}$ & $\begin{array}{l}+20 /-30 \\
+40 /-30\end{array}$ \\
\hline $\begin{array}{l}\text { 5. 3,4 Dihydroxy- } \\
\text { phenylacetic acid }\end{array}$ & E.L. & 0.324 & -104 & $-15 /-5$ \\
\hline 6. $\alpha$-Methyl-dopa & D.C. & 450 & -150 & $-20 /-10$ \\
\hline 7. Dopamine & $\begin{array}{l}\text { S.L. } \\
\text { M.H. }\end{array}$ & $\begin{array}{l}1.060 \\
7.660\end{array}$ & $\begin{array}{l}-\quad 77 \\
-\quad 364\end{array}$ & $\begin{array}{r}-10 /-10 \\
0 /-15\end{array}$ \\
\hline $\begin{array}{l}\text { 8. 3,4 Dihydroxy } \\
\text { mandelic acid }\end{array}$ & V.C. & 0.464 & +34 & $-15 /-10$ \\
\hline $\begin{array}{l}\text { 9. 3-Methoxy, 4-hydroxy } \\
\text { mandelic acid }\end{array}$ & M.E. & 0.364 & -355 & $-5 / 0$ \\
\hline 10. DL-metanephrine & $\begin{array}{l}\text { A.McD. } \\
\text { T.B. }\end{array}$ & $\begin{array}{l}0.324 \\
0.648\end{array}$ & $\begin{array}{l}-\quad 38 \\
-\quad 29\end{array}$ & $\begin{array}{l}0 / 0 \\
0 / 8\end{array}$ \\
\hline 11. Normetanephrine & H.P. & 1.620 & +13 & $+5 / 0$ \\
\hline 12. Ephedrine & $\begin{array}{l}\text { J.W. } \\
\text { P.B. } \\
\text { P.C. } \\
\text { M.A. }\end{array}$ & $\begin{array}{l}16 \\
16.5 \\
22.32 \\
24.00\end{array}$ & $\begin{array}{l}+242 \\
+179 \\
+122 \\
+179\end{array}$ & $\begin{array}{l}+10 /+5 \\
+10 / 0 \\
+12 / 0 \\
+12 /-10\end{array}$ \\
\hline 13. Phenylephrine & $\begin{array}{l}\text { A.H. } \\
\text { D.C. } \\
\text { J.M. }\end{array}$ & $\begin{array}{l}0.780 \\
0.540 \\
0.540\end{array}$ & $\begin{array}{l}+121 \\
+124 \\
-\quad 60\end{array}$ & $\begin{array}{l}+44 /+15 \\
+50 /+32 \\
+30 /+20\end{array}$ \\
\hline 14. Metaraminol & V.S. & 1.08 & +117 & $+30 /+15$ \\
\hline 15. Mephentermine & $\begin{array}{l}\text { A.D. } \\
\text { L.C. } \\
\text { J.F. } \\
\text { T.F. }\end{array}$ & $\begin{array}{l}12 \\
16 \\
16.2 \\
21.1\end{array}$ & $\begin{array}{r}+323 \\
+126 \\
+\quad 54 \\
+\quad 70\end{array}$ & $\begin{array}{l}+10 /+5 \\
+15 /+15 \\
+20 /+10 \\
+40 /+20\end{array}$ \\
\hline 16. Methoxamine & R.P. & 13 & -40 & $+60 /+10$ \\
\hline 17. Vasopressin & J.J. & $\begin{array}{l}1.08 \mu \\
1.08 \mu\end{array}$ & $\begin{array}{l} \pm \quad 95 \\
\pm \quad 18\end{array}$ & $\begin{array}{r}+5 /+5 \\
+15 /+8\end{array}$ \\
\hline 18. Angiotensin & $\begin{array}{l}\text { H.B. } \\
\text { C.W. } \\
\text { L.L. } \\
\text { B.H. } \\
\text { T.H. } \\
\text { F.B. }\end{array}$ & $\begin{array}{l}0.006 \\
0.017 \\
0.017 \\
0.017 \\
0.017 \\
0.028\end{array}$ & $\begin{array}{rr} & 161 \\
+ & 126 \\
+\quad 32 \\
+\quad 76 \\
+\quad 26 \\
+\quad 18\end{array}$ & $\begin{array}{l}+66 /+41 \\
+25 /+28 \\
+30 /+20 \\
+15 /+20 \\
+20 /+30 \\
+15 /+16\end{array}$ \\
\hline
\end{tabular}

or vasoactive dose of norepinephrine or epinephrine.

\section{DISCUSSION}

Figure 1 illustrates the presently formulated outline of the biogenesis and degradation of norepinephrine and epinephrine. It was the intent of this study to test as many of the compounds involved in the sequence of chemical events as were available. Of the six compounds actually assayed. neither the two before (dopamine and dopa ${ }^{1}$ ) nor the four degradative products after (3,4-dihydroxy mandelic acid; 3-methoxy.4-hydroxy mandelic acid; normetanephrine; metanephrine) nor-

$1 \alpha$-Methyl-dopa was actually studied, since the addition (rather than any substitution) of a methyl function was not considered inhibiting to a fat mobilizing agent. 


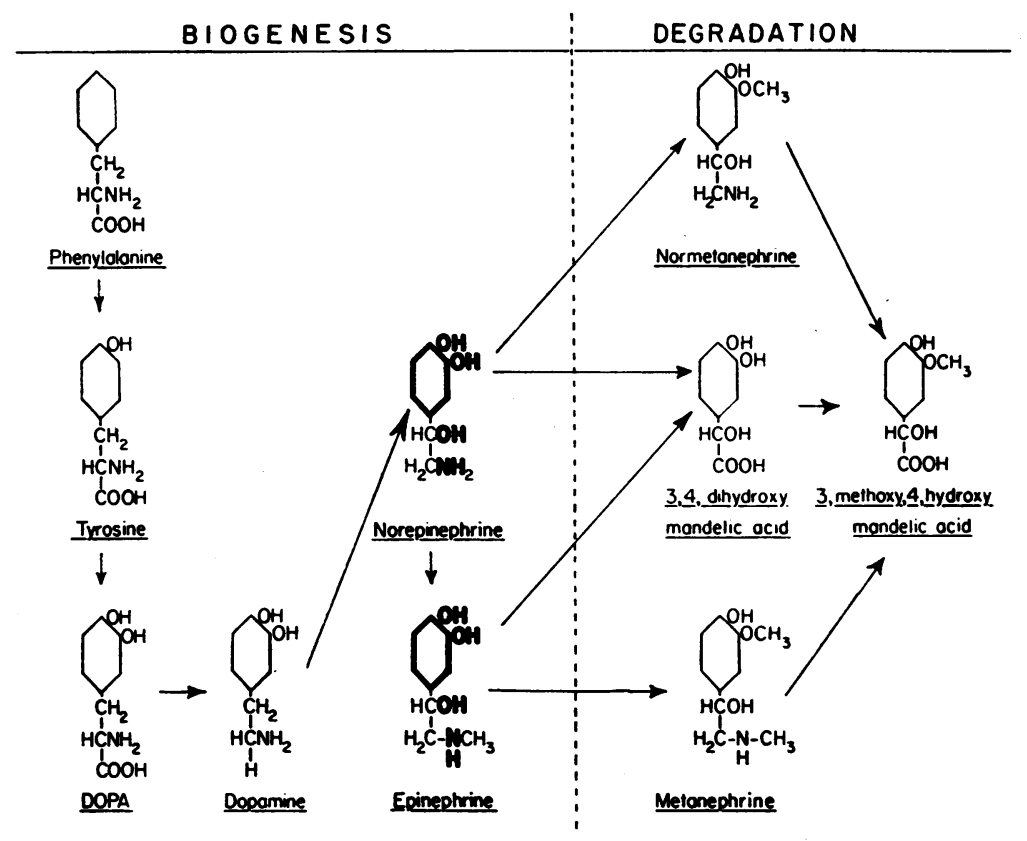

Fig. 1. SChEME of BIogenesis AND DEgradation of EPINEPHRINE AND NOREPINEPHRINE. Chemical groups in bold outline are the units considered to be necessary for fat-mobilization effect in man.

epinephrine and epinephrine had any significant effect upon the plasma FFA level. These observations led us to believe that the structural configuration of the active compounds may be spe- cific for the fat mobilizing effect, and, accordingly, the series of compounds illustrated in Figure 2 was studied. It will be noted that whenever either or both hydroxyl functions in the phenyl ring
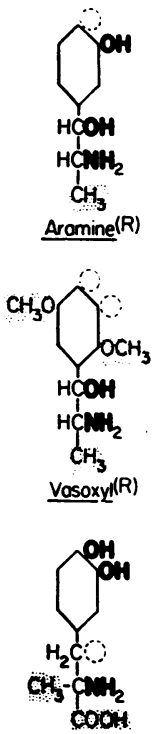

a-methy-DOPA

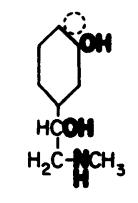

Neosynephrine
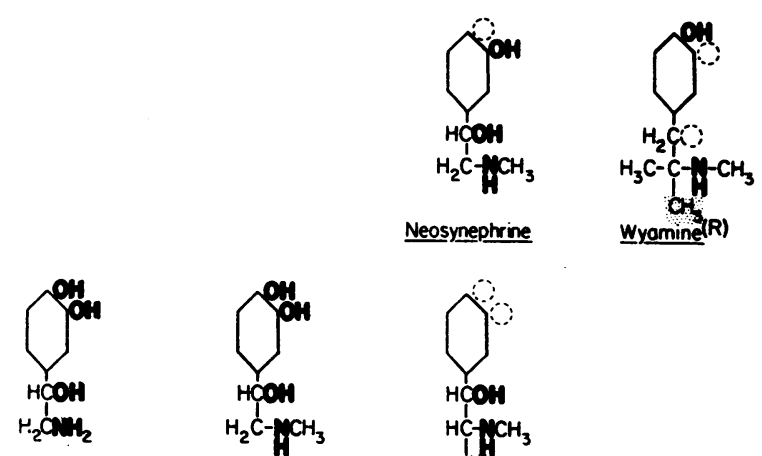

Norepinephrine

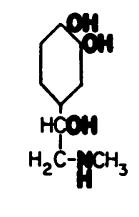

Epinephrine
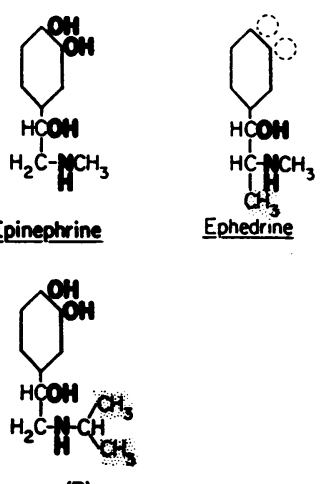

Isuprel(R)

Fig. 2. Structural configuration of a series of Compounds infused INTO MAN. Chemical groups in bold outline are the units considered to be necessary for fat mobilization in man. Dashed circles indicate absence of a hydroxyl group. Shaded groups indicate addition of a group. See text for FFA response. 
were removed [phenylephrine (Neo-synephrine), ephedrine, metaraminol (Aramine), methoxamine (Vasoxyl)] or altered (normetanephrine), FFA effect was lost. The loss of one of the phenyl hydroxyl (3-hydroxy) and the $\beta$-carbon hydroxyl group [mephentermine (Wyamine)] also resulted in inactivity. The loss of the $\beta$-carbon hydroxyl (dopamine) also modified activity. The addition of two methyl groups to the carbon already bound to the amino nitrogen (isoproterenol) does not modify fat-mobilizing activity. These several structural alterations do not, however, completely remove the vasoactive property of these compounds (Table I). Figures 1 and 2 have been drawn so as to emphasize the four chemical groups which must be present in relationship to the benzene ring to cause a fat-mobilizing response. The FFA activity of isoproternol, containing the four groups, should be noted, because it is a synthetic compound in which the structural alterations have resulted in changes in the specific cardiovascular effect, but in which the fat-mobilizing effect is still present.

The studies of the vasoactive polypeptides were conducted in order to test whether the vascular effects were comparably separable from any lipolytic effects; the absence of any plasma FFA increase would indicate that such an independence of activity does exist.

\section{SUMMARY}

1. The effect of the intravenous infusion of a series of catechol compounds and vasoactive polypeptides upon the plasma free fatty acid level of fasting, resting individuals was studied.

2. The presence of a benzene ring with two hydroxyl groups in the 3 and 4 position, a $\beta$-carbon hydroxyl and an amino group attached to the $\alpha$-carbon atom are the four concomitant chemical functions necessary for effective fat mobilizing property in man.

3. Although the polypeptides studied demonstrated vascular activity, no lipid-mobilizing effect was noted, further supporting the suggested specificity of the chemical structure necessary for fat mobilization.

\section{REFERENCES}

1. Dole, V. P. A relation between non-esterified fatty acids in plasma and the metabolism of glucose. J. clin. Invest. 1956, 35, 150.

2. White, J. E., and Engel, F. L. A lipolytic action of epinephrine and norepinephrine on rat adipose tissue in vitro. Proc. Soc. exp. Biol. (N. Y.) 1958, 99, 375 .

3. Klein, R. F., Estes, E. H., Jr., and Bogdonoff, M. D. Effect of norepinephrine on plasma free fatty acid level in man. J. appl. Physiol. 1961, 16, 342.

4. Trout, D. L., Estes, E. H., Jr., and Friedberg, S. J. Titration of free fatty acids of plasma: A study of current methods and a new modification. J. Lip. Res. 1960, 1, 199. 